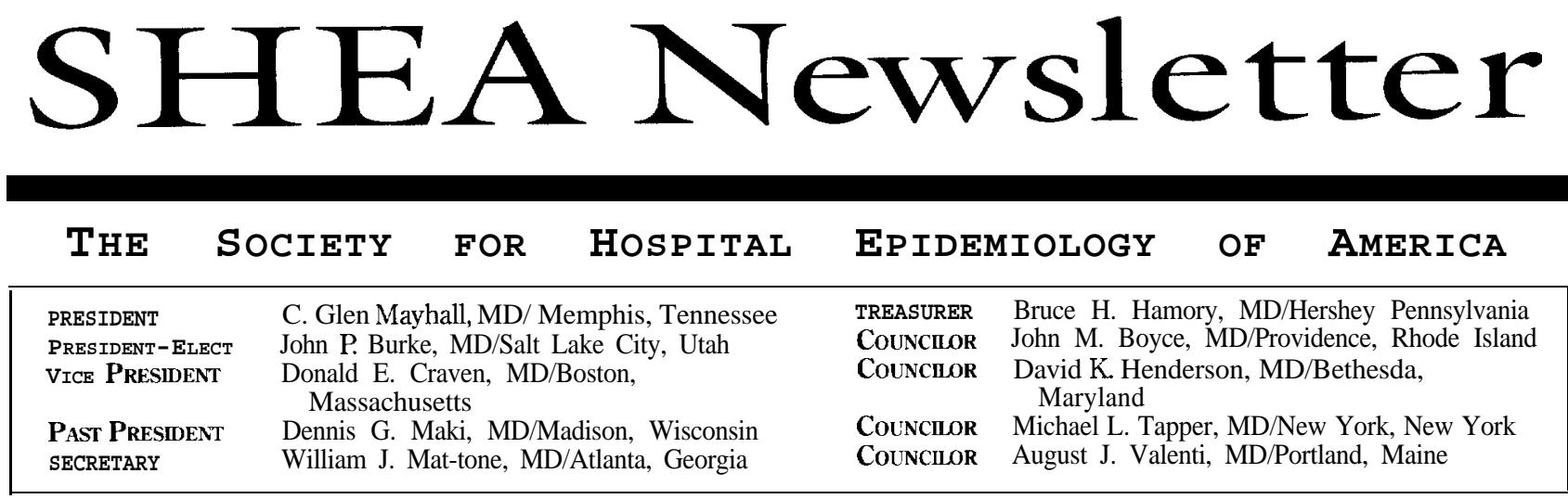

\title{
SHEA Makes Front Page News
}

In a front page story in the December 27, 1990, national edition of the New Y ork Times, medical news writer Lawrence Altman, MD, quoted the SHEA/APIC position paper on the human immunodeficiency virus (HIV)-infected healthcare worker that appeared in the December issue of Infection Control and Hospital Epidemiology.

The Times article noted that HIV testing of doctors is the crux of a thorny debate on U.S. policy, and that the SHEA/APIC "position paper...in part, said, 'Broad proscriptions of clinical practice are clearly unwarranted.' But the groups said healthcare workers with any infection carried in the blood should be counseled to avoid procedures that have been epidemiologically linked to their transmission."

Now, in the wake of further evidence of transmission of HIV infection during an invasive dental procedure (M M WR. 1991;40:21), the Centers for Disease Control (CDC) convened a meeting in Atlanta, Georgia, on February 21-22, 1991, to review risk of transmission of HIV and hepatitis B virus (HBV) to patients during invasive procedures and to assess implications of these risks. SHEA was one of a handful of national groups invited to present brief position papers at that meeting. More on this meeting next month.

\section{Nominating Committee Chair Appointed for 1991}

Dale N. Gerding, MD, has been appointed chairperson of the Nominating Committee for 1991. The Committee will develop a slate of candidates for the election, to be held in the fall of 1991, for offices to be filled in
January 1992. The Committee will nominate candidates for vice president, treasurer, and two of the councilor offices. Members of SHEA who wish to suggest names to the Committee for consideration as candidates should submit the name(s) in writing to Dr. Gerding by June 1 , 1991, at VA Medical Center, 111F, 1 Veterans' Drive, Minneapolis, MN 55417. His telephone number is (612) 725-4185.

\section{Strategic Planning Meeting}

\footnotetext{
January 11-12, 1991, SHEA board members and key committee chairpersons met for a strategic planning retreat. Russell Coile, Jr., President of Health Forecasting Group, served as the groups facilitator.

At last year's strategic planning session, the board identified a series of key survival
}

functions (see the May 1990 newsletter) that were undertaken in 1990. This laid the groundwork for this year's session, which outlined an ambitious five-year timetable for key SHEA activities, such as our educational courses, annual scientific meetings, membership surveys and recruitment, membership direc- tory updates, position papers, and policy development and promotion.

This years meeting was organized with the assistance of Andy Riley, our Executive Director, and Neil Cronin, from Merck Sharp and Dohme, which provided a grant to cover the cost of the meeting. 